\title{
PREVALENCE OF ANAEMIA IN FIRST MBBS STUDENTS IN A RURAL MEDICAL COLLEGE
}

\author{
Chitrawati Bal Gargade1, Suvarna Netaji Patil2
}

${ }^{1}$ Associate Professor, Department of Pathology, BKL Walawalkar Rural Medical College, Maharashtra. ${ }^{2}$ Assistant Professor, Department of Medicine, BKL Walawalkar Rural Medical College, Maharashtra.

\begin{abstract}
Anaemia is one of the most commonly recognized disorders. Adolescence is a vulnerable period in the human life cycle for the development of anaemia. Anaemia is seen in both developing and developed countries and so also in rural and urban population, literate and illiterate people. Study was done to assess the level of anaemia among first (I) MBBS medical students and its relation to Body Mass Index (BMI). Anaemia prevalence was 29.0\% among medical students. Out of these $6.9 \%$ were male and $93.1 \%$ were female. Out of 60 female students, 27(45\%) were anaemic and out of them 7(25.9\%) were underweight. No correlation was found in between body mass index and anaemia. Anaemia is also prevalent in literate medical students who are aware about health and disease and the cause of anaemia should be sought and treated in these upcoming doctors.
\end{abstract}

\section{KEYWORDS}

Anaemia, Medical Students, Haemoglobin Level, Body Mass Index.

HOW TO CITE THIS ARTICLE: Gargade CB, Patil SN. Prevalence of anaemia in first MBBS students in a rural medical college. J. Evolution Med. Dent. Sci. 2016;5(25):1329-1331, DOI: 10.14260/jemds/2016/312

\section{INTRODUCTION}

Anaemia is a global public health problem that affects both developing and developed countries with major consequences for human health as well as social and economic development. More than half of the world's undernourished population lives in India. ${ }^{1}$ and half of Indian children and women are malnourished. ${ }^{2}$ Nutritional deficiencies leading to anaemia could have detrimental effect on health of future doctors and health care providers. Anaemia during adolescence severely impairs the physical and mental development; weakens behavioural and cognitive development; reduces physical fitness; decreases the work performance. . $^{3,4}$

BMI is age and sex independent and a known epidemiological marker of nutritional status of adolescents. Hence, this study was taken to know the prevalence of anaemia and its correlation with nutritional status of the medical students.

\section{MATERIALS AND METHODS}

This cross-sectional study was conducted to estimate the prevalence of anaemia among the students of rural Medical College in Konkan area of Maharashtra after Ethical Committee approval. Haemoglobin levels of 100 newly admitted first MBBS students were measured on cell counter during month of September 2015. Anthropometric measurements of students like height and weight were noted. Complete blood count with peripheral smear examination was done.

Statistical analysis was done by using SPSS software for Windows (Version 16). Subjects were divided into anaemic and normal subjects according to haemoglobin value.

Financial or Other, Competing Interest: None.

Submission 11-02-2016, Peer Review 07-03-2016,

Acceptance 12-03-2016, Published 26-03-2016.

Corresponding Author:

Dr. Chitrawati Bal Gargade

Department of Pathology,

BKL Walawalkar Rural Medical College

Derwan A/P Sawarde, Tal-Chiplun,

Dist-Ratnagiri, Maharashtra

Pin-415606.

E-mail: chitragargade@yahoo.com

DOI: $10.14260 /$ jemds $/ 2016 / 312$
Anaemia is established if the haemoglobin is below than cut-off points as recommended by WHO. ${ }^{5}$ Cut-off points for the diagnosis of anaemia in adult males $13.0 \mathrm{~g} / \mathrm{dL}$ and adult nonpregnant females is $12.0 \mathrm{~g} / \mathrm{dL}$. BMI was graded based on WHO classification for Asian adults. ${ }^{6}$

The relationship between haemoglobin $(\mathrm{Hb})$ concentration and BMI was examined by calculating the Pearson's correlation coefficient $(r)$ and the significance of correlation (p).

\section{RESULTS}

There were $60(60 \%)$ female and $40(40 \%)$ male students admitted in rural medical college of Konkan region in Maharashtra. Anaemia prevalence was $29.0 \%$ among medical students. In our study, we observed that out of 100 students 29 were anaemic. Out of 29 anaemic students, 2 (6.89\%) were male and 27 (93.1\%) were female as seen in Fig. 1.

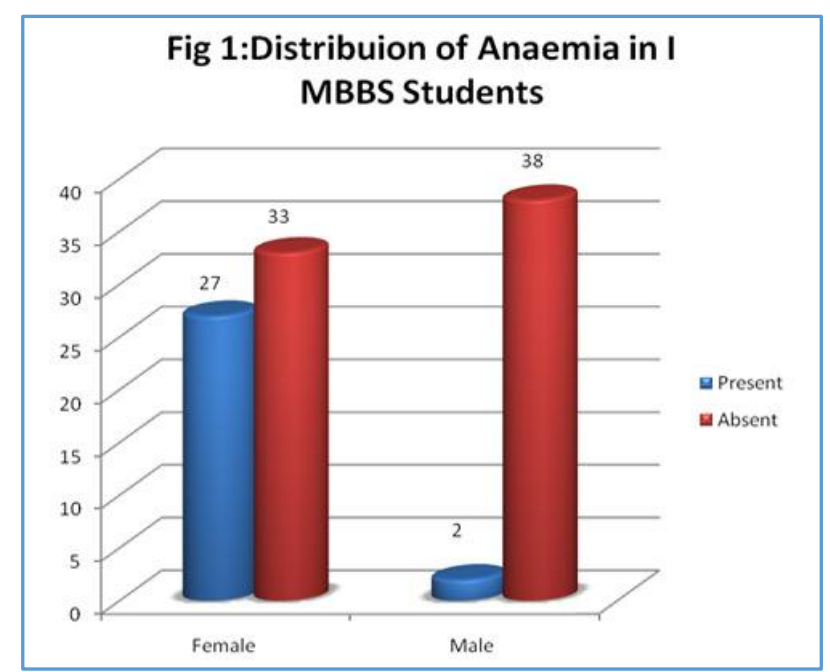

Anaemia was more prevalent in female students than male students as seen in Table No. 1. It shows out of 60 female students $27(45 \%)$ were anaemic, while out of 40 male students only $2(5 \%)$ were anaemic.

\begin{tabular}{|c|c|c|}
\hline Parameters & Males & Females \\
\hline Anaemic & $2(5 \%)$ & $27(45 \%)$ \\
\hline Non Anaemic & $38(95 \%)$ & $33(55 \%)$ \\
\hline Total & $40(100 \%)$ & 60 \\
\hline
\end{tabular}


Majority of students had mild grade of anaemia (86.2\%), which was seen in girls. Both anaemic boys had mild anaemia. None had severe anaemia.

\begin{tabular}{|c|c|c|}
\hline Severity & Males (\%) & Females (\%) \\
\hline Mild & $2(6.9)$ & $23(79.3 \%)$ \\
\hline Moderate & - & $4(13.8 \%)$ \\
\hline Severe & - & - \\
\hline \multicolumn{3}{|c|}{ Table 2: Severity of Anaemia among Medical Studen } \\
\hline
\end{tabular}

AS per WHO.7 the students are divided into Overweight $\left(25-29.9 \mathrm{~kg} / \mathrm{m}^{2}\right)$, Normal $\left(18.5-24.9 \mathrm{~kg} / \mathrm{m}^{2}\right)$, Underweight $\left(<18.5 \mathrm{~kg} / \mathrm{m}^{2}\right)$. A BMI of over $30 \mathrm{~kg} / \mathrm{m}^{2}$ is considered obese. Fig. 2 shows distribution of anaemia and BMI in first MBBS students.

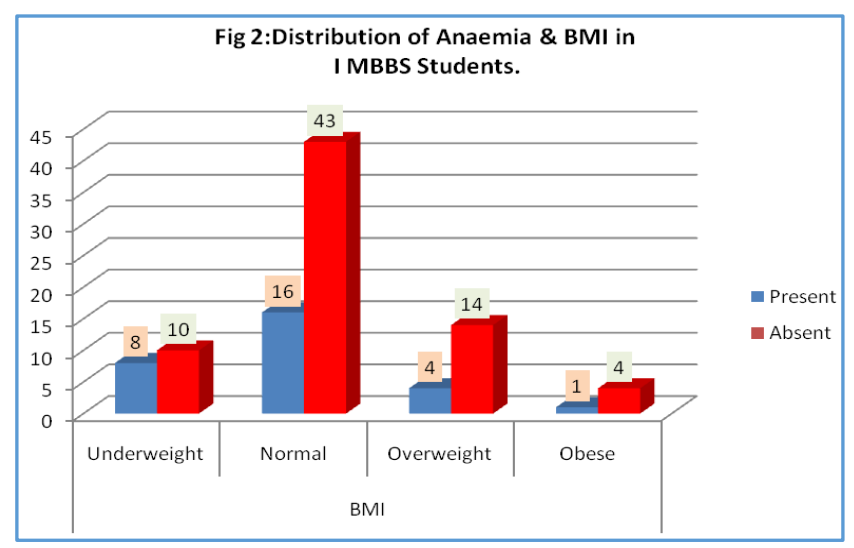

Table 3 shows cross tabulation of anaemia and BMI status in I MBBS female students.

\begin{tabular}{|c|c|c|c|c|c|}
\hline $\begin{array}{c}\text { Anaemia } \\
\text { in Female }\end{array}$ & \multicolumn{2}{|c|}{$\begin{array}{c}\text { BMI Status } \\
\text { in Female }\end{array}$} & & \\
\hline & $\begin{array}{c}\text { Under } \\
\text { weight }\end{array}$ & Normal & $\begin{array}{c}\text { Over } \\
\text { weight }\end{array}$ & Obese & Total \\
\hline Present & 7 & 15 & 4 & 1 & 27 \\
\hline Absent & 3 & 22 & 8 & 0 & 33 \\
\hline Total & $\mathbf{1 0}$ & $\mathbf{3 7}$ & $\mathbf{1 2}$ & $\mathbf{1}$ & $\mathbf{6 0}$ \\
\hline Table 3: Anaemia and BMI Correlation among Female I MBBS \\
Students
\end{tabular}

Table 3 shows correlation between BMI and Anaemia among the female anaemic students, about half (55.6\%) were found normal weight, $25.9 \%$ were underweight and $14.8 \%$ were overweight and 1 female (3.7\%) was obese.

\begin{tabular}{|c|c|c|c|}
\hline \multicolumn{4}{|c|}{ Chi-Square Tests } \\
\hline & Value & df & $\begin{array}{l}\text { Asymp. Sig. } \\
\text { (2-sided) }\end{array}$ \\
\hline Pearson Chi-Square & $4.705 a^{a}$ & 3 & .195 \\
\hline Likelihood Ratio & 5.122 & 3 & .163 \\
\hline $\begin{array}{l}\text { Linear-by-Linear } \\
\text { Association }\end{array}$ & 1.210 & 1 & .271 \\
\hline $\mathrm{N}$ of Valid Cases & 60 & & \\
\hline \multicolumn{4}{|c|}{$\begin{array}{l}\text { a. } 3 \text { cells }(37.5 \%) \text { have expected count less than } 5 \text {. The } \\
\text { minimum expected count is } .45\end{array}$} \\
\hline
\end{tabular}

Here, Chi-Square statistics value is 4.705 and as $\mathrm{p}$ value (Asymp. Sig. (2-sided) is 0.195 , which is greater than 0.05 indicates that there is no correlation between nutritional status and anaemia in females of I MBBS Students). This is also proved by Spearman Correlation (0.169) and Pearson's Correlation (0.143) as indicated in below table.

\begin{tabular}{|c|c|c|c|c|c|}
\hline \multicolumn{7}{|c|}{ Symmetric Measures } \\
\hline & Value & $\begin{array}{c}\text { Asymp. } \\
\text { Std. } \\
\text { Error. }^{\text {a }}\end{array}$ & $\begin{array}{c}\text { Approx. } \\
\text { T.b }\end{array}$ & $\begin{array}{c}\text { Approx } \\
\text {. Sig. }\end{array}$ \\
\hline $\begin{array}{c}\text { Nominal } \\
\text { by } \\
\text { Nominal }\end{array}$ & $\begin{array}{c}\text { Contingency } \\
\text { Coefficient }\end{array}$ & .270 & & .195 \\
\hline $\begin{array}{c}\text { Interval } \\
\text { by } \\
\text { Interval }\end{array}$ & Pearson's R & .143 & .133 & 1.102 & $.275 .^{\text {c }}$ \\
\hline $\begin{array}{c}\text { Ordinal } \\
\text { by } \\
\text { Ordinal }\end{array}$ & $\begin{array}{c}\text { Spearman } \\
\text { Correlation }\end{array}$ & .169 & .129 & 1.309 & $.196 .^{c}$ \\
\hline \multicolumn{2}{|c|}{ N of Valid Cases } & 60 & & & \\
\hline $\begin{array}{c}\text { a. Not assuming the null } \\
\text { hypothesis }\end{array}$ & & & \\
\hline $\begin{array}{l}\text { b. Using the asymptotic standard error } \\
\text { assuming the null hypothesis }\end{array}$ & & \\
\hline
\end{tabular}

Table 4 shows Correlation between BMI status and Anaemia in I MBBS male candidates.

\begin{tabular}{|c|c|c|c|c|c|}
\hline $\begin{array}{c}\text { Anaemia } \\
\text { in Male }\end{array}$ & \multicolumn{2}{|c|}{$\begin{array}{c}\text { BMI Status } \\
\text { in Male }\end{array}$} & & \\
\hline & $\begin{array}{c}\text { Under } \\
\text { weight }\end{array}$ & Normal & $\begin{array}{c}\text { Over } \\
\text { weight }\end{array}$ & Obese & Total \\
\hline Present & 1 & 1 & 0 & 0 & 2 \\
\hline Absent & 7 & 21 & 6 & 4 & 38 \\
\hline Total & $\mathbf{8}$ & $\mathbf{2 2}$ & $\mathbf{6}$ & $\mathbf{4}$ & $\mathbf{4 0}$ \\
\hline Table 4: Anaemia and BMI Correlation among I MBBS Male \\
Candidates
\end{tabular}

Out of two anaemic male students, one had normal BMI, while the other was underweight.

\begin{tabular}{|c|c|c|c|c|c|}
\hline \multicolumn{6}{|c|}{ Chi-Square Tests } \\
\hline & Value & df & \multicolumn{3}{|c|}{$\begin{array}{l}\text { Asymp. Sig. } \\
\text { (2-Sided) }\end{array}$} \\
\hline $\begin{array}{l}\text { Pearson Chi- } \\
\text { Square }\end{array}$ & $1.483 .^{\mathrm{a}}$ & 3 & \multicolumn{3}{|c|}{.686} \\
\hline $\begin{array}{l}\text { Likelihood } \\
\text { Ratio }\end{array}$ & 1.717 & 3 & \multicolumn{3}{|c|}{.633} \\
\hline $\begin{array}{l}\text { Linear-by- } \\
\text { Linear } \\
\text { Association }\end{array}$ & 1.192 & 1 & \multicolumn{3}{|c|}{.275} \\
\hline $\begin{array}{l}\mathrm{N} \text { of Valid } \\
\text { Cases }\end{array}$ & 40 & & & & \\
\hline \multicolumn{6}{|c|}{$\begin{array}{l}\text { a. } 5 \text { cells }(62.5 \%) \text { have expected count less than } 5 \text {. The minimum } \\
\text { expected count is . } 20\end{array}$} \\
\hline \multicolumn{6}{|c|}{$\begin{array}{c}\text { Symmetric Measures } \\
\end{array}$} \\
\hline & & Value & $\begin{array}{l}\text { Asymp } \\
\text {. Std. } \\
\text { Error.a }\end{array}$ & $\begin{array}{l}\text { Appro } \\
\text { x. T. }\end{array}$ & $\begin{array}{l}\text { Appro } \\
\text { x. Sig. }{ }^{\text {a }}\end{array}$ \\
\hline $\begin{array}{l}\text { Nominal by } \\
\text { Nominal }\end{array}$ & $\begin{array}{l}\text { Conting } \\
\text { ency } \\
\text { Coeffi- } \\
\text { cient }\end{array}$ & .189 & & & .686 \\
\hline $\begin{array}{l}\text { Interval by } \\
\text { Interval }\end{array}$ & $\begin{array}{l}\text { Pearson' } \\
\text { s R }\end{array}$ & .175 & .109 & 1.095 & $.281^{\mathrm{c}}$ \\
\hline $\begin{array}{l}\text { Ordinal by } \\
\text { Ordinal }\end{array}$ & $\begin{array}{c}\text { Spearma } \\
\text { n } \\
\text { Correla- } \\
\text { tion }\end{array}$ & .186 & .128 & 1.169 & $.250^{\mathrm{c}}$ \\
\hline \multicolumn{2}{|c|}{$\mathrm{N}$ of Valid Cases } & 40 & & & \\
\hline \multicolumn{2}{|c|}{$\begin{array}{l}\text { a. Not assuming the null } \\
\text { hypothesis }\end{array}$} & & & & \\
\hline
\end{tabular}

Here, Chi- Square statistics value is 1.483 and as $\mathrm{p}$ value (Asymp. Sig. (2-sided) is 0.686 , which is greater than 0.05 indicates that there is no correlation between nutrition status and anaemia in males of I MBBS Students). This is also proved by Spearman Correlation (0.186) and Pearson's Correlation (0.186) as indicated in above table. 


\section{DISCUSSIONS}

In this study 29\% students were anaemic, of whom $93.1 \%$ were female. Thus, anaemia was found to be much more common among females than males. The prevalence of anaemia among underweight was $27.6 \%$ and in students with normal BMI were 55.2\%. Overweight and obese anaemic students constitute $13.6 \%$ and $3.4 \%$ respectively.

The prevalence of anaemia among young adult medical students in study done in Lucknow was $59 \%$, where $72 \%$ of the female students and $52 \%$ of the male students were detected to be anaemic. ${ }^{8}$

In study by Bano R. ${ }^{9} 32.0 \%$ students were anaemic with $44.0 \%$ girls and $20.0 \%$ boys.

The overall prevalence of anaemia was found to be $39 \%$ with preponderance among female students (56\%) as compared to male students $(22 \%)$ in study done among undergraduate medical students of Central India. 10

In our study two male students were anaemic with Haemoglobin less than 13, but more than $12.0 \mathrm{~g} / \mathrm{dL}$. In study by Yogesh Saxena. ${ }^{11}$ none of the boys had haemoglobin less than $13 \mathrm{~g} / \mathrm{dL}$.

In present study, total 12 female students were overweight and out of them $33.3 \%$ were anaemic, 10 female students were underweight and out of them $70.0 \%$ were anaemic. Out of 37 normal weight female students, 15 (40.5\%) were anaemic.

In females no association was seen between BMI and $\mathrm{Hb}$ in our study contrast to study by Yogesh Saxena. ${ }^{11}$ In their study, a negative association of BMI to $\mathrm{Hb}$ concentration was observed among girls who were overweight and obese. In our study, only one female student was obese and was anaemic having haemoglobin $11.2 \mathrm{gm} / \mathrm{dL}$.

While Waseem SM and et al.12 in their studies have reported significant correlation of $\mathrm{BMI}$ with $\mathrm{Hb}$ in males, but non-significant negative correlation between BMI and HB in females.

Pandey S and Pal A showed that anaemia decreases with increase in nutritional status. $(13,14)$

In present study, prevalence of anaemia among female first MBBS students accounted $45 \%$ which is similar to our previous study done from the same geographical area. It showed $41 \%$ prevalence of anaemia in adolescent girls and $2 / 3^{\text {rd }}$ of them were underweight. ${ }^{15}$ However, only $1 / 4^{\text {th }}$ (25.9\%) of anaemic MBBS female students were underweight.

\section{CONCLUSION}

Anaemia is prevalent even in medical students who are well educated and well oriented about the nutrition and its effect on health. No association was seen among the BMI and prevalence of anaemia. Hence some more parameters besides nutrition also should be sought like menstrual irregularities, underlying diseases to look for the cause of anaemia in these female upcoming doctors. Being suffered by anaemia, these upcoming health care providers may campaign against anaemia in their professional practice later in a better way.

\section{REFERENCES}

1. Ganz T. Hepcidin, a key regulator of iron metabolism and mediator of anemia of inflammation. Blood 2003;102(3):783-8.

2. Krishnaswami K. Country profile: India. Nutritional disorders-old and changing. Lancet 2000;351(9111):1268-9.

3. Nelson M, Bakaliou F, Trivedi A. Iron-deficiency anaemia and physical performance in adolescent girls from different ethnic backgrounds. British Journal of Nutrition 1994;72(03):427-33.

4. Dallmon PR. Iron deficiency: does it matter?J Intern Med 1989;226:367-72.

5. Iron deficiency anaemia: Assessment, Prevention, and Control: a guide for programme managers. WHO 2001. www.who.int/nutrition/publications.

6. Misra A, Chowbey P, Makkar BM, et al. Consensus statement for diagnosis of obesity, abdominal obesity and the metabolic syndrome for Asian Indians and recommendations for physical activity, medical and surgical management. JAPI 2009;57(2):163-70.

7. WHO EC. Appropriate body-mass index for Asian populations and its implications for policy and intervention strategies. Lancet 2004;363(9403):157-63.

8. Sehgal S, Kapoor R. Prevalence of anaemia among the first year students in a medical teaching institution in Lucknow. J Biol Chem Research 2015;32(2):460-70.

9. Bano R, Ahmad N, Sharma BC, et al. Nutritional anemia in the medical students. Indian Med Gaz 2012;1:16-8.

10. Khan B, Sukhsohale ND, Jawade P. Prevalence of anemia among undergraduate medical students of central India. Global journal for research analysis 2015;4(5):13-4.

11. Saxena Y, Shrivastava A, Saxena V. Effect of gender on correlation of anaemia with body mass index in medical students. Indian J Physiol Pharmacol 2011;55(4):364-9.

12. Waseem SM, Bano $\mathrm{R}$, Ahmad $\mathrm{N}$, et al. Study of haematological profile and body mass index in undergraduate medical students in Lucknow, Uttar Pradesh. International Journal of Health Sciences and Research (IJHSR) 2015;5(6):257-62.

13. Pandey S, Singh A. A cross sectional study of nutritional anemia among medical students in a medical college at Bilaspur, Chattisgarh. National J of Medical Research 2013;3(2):143-6.

14. Pal A, De S, Sengupta $P$, et al. An investigation on prevalence of anemia in relation to BMI and nutrient intake among adult rural population of West Bengal, India. Epidemiology, Biostatistics and Public Health 2014;11(2):e8915-1-10.

15. Patil SN, Wasnik V, Wadke R. Health problems amongst adolescent girls in rural areas of ratnagiri district of maharashtra India. J of Clinical and Diagnostic Research 2009;3(5):1784-90. 